Vol. V No. 2 Oktober 2015

\title{
GOOD ENVIRONMENTAL GOVERNANCE (STUDI KASUS PENGELOLAAN TAMAN MACAN DI KOTA MAKASSAR)
}

\author{
Nur Faisah'1, Andi Luhur Prianto' ${ }^{1}$ \\ 1Program Studi Ilmu Pemerintahan Fakultas Ilmu Sosial dan Ilmu Politik \\ Universitas Muhammadiyah Makassar \\ Jl. Sultan Alauddin No. 259 Makassar 90221 \\ Telp. 0411-866972 ext.107. Fax.0411-8655888 \\ nurfaisah93@gmail.com, luhur@unismuh.ac.id
}

\begin{abstract}
This study aims to determine the government's efforts and collaboration between government, private sektor and communities in the management of one of the parks in the city of Makassar are tiger parks to realize that good environmental governance. This type of research is qualitative descriptive study. Data collected by using interviews, observation and documentation. The results showed that the management of the park to develop principles of good governance. The rule of law that houses the park management tigers in Makassar, the mutual openness both in terms of supervision of the management of the park and in cooperation between civil servants and managers of parks and implement aspects of collaboration such as government oversight of performance management, private give support form of waste banks and the public as well as the macan park observer.
\end{abstract}

Keywords : Good Environmental Governance

\begin{abstract}
ABSTRAK
Penelitian ini bertujuan untuk mengetahui upaya pemerintah serta kolaborasi antara pemerintah, swasta dan masyarakat dalam pengelolaan salah satu taman yang berada di Kota Makassar yaitu taman macan sehingga terwujud tata kelola lingkungan yang baik (good environmental governance). Jenis penelitian yang digunakan adalah penelitian deskriptif kualitatif. Data dikumpulkan dengan menggunakan teknik wawancara, observasi dan dokumentasi. Hasil penelitian menunjukkan bahwa pengelolaan taman mengembangkan prinsip good governance. Rule of law (aturan hukum), aturan hukum yang menaungi pengelolaan taman macan di Kota Makassar, adanya saling keterbukaan baik dalam hal pengawasan pengelolaan taman maupun dalam kerja sama antara pegawai dinas dan pengelola taman serta menerapkan aspek kolaborasi yaitu pemerintah melakukan pengawasan kinerja pengelolaan, swasta memberikan sumbangsi berupa bank sampah dan masyarakat sebagai pengguna sekaligus pengamat taman macan.
\end{abstract}

Kata kunci : Good Environmental Governance 


\section{A. PENDAHULUAN}

Kota sebagai pusat dari segala usaha dan aktifitas manusia, merupakan tempat yang selalu menjadi tujuan dan daya tarik untuk dikunjungi oleh masyarakat. Ketertarikan ini membuat Kota menjadi tempat yang tak pernah berhenti untuk membangun sarana dan prasarana demi mendukung kenyamanan hidup di perkotaan. Adapun sarana dan prasarana yang dibangun dalam meningkatkan kenyamanan masyarakat yaitu ruang terbuka hijau yang mana di bangun hutan Kota berfungsi sebagai tempat rekreasi dimana penduduk dapat melaksanakan kegiatan berbentuk rekreasi, berupa kegiatan rekreasi aktif seperti lapangan olahraga, dan rekreasi pasif seperti taman.

Jika dilihat dengan seksama, Kota Makassar pada sekarang ini telah memiliki beberapa ruang terbuka hijau yang di antaranya termasuk hutan Kota yang telah di kelola oleh pemerintah yang telah difungsikan dengan baik. Dengan melakukan pengelolaan ruang terbuka hijau secara baik dan benar diharapkan akan dapat memberikan manfaat bagi kita, diantaranya dapat memperindah Kota, menyejukkan udara Kota, mengurangi kebisingan, menyerap dan meresap polusi, sebagai sarana rekreasi, penelitian dan habitat bagi aneka ragam mahluk hidup, dan masih banyak lagi manfaat lainnya. Dengan manfaat yang kita rasakan tersebut, maka pembangunan, penataan dan pengembangan ruang terbuka hijau harus dapat dilaksanakan secara baik dan terpadu. Saat ini setiap daerah telah memiliki otonomi daerah, dengan demikian Pemerintah Daerah seharusnya lebih memperhatikan kualitas lingkungan Kotanya masing-masing agar menjadi tempat yang sehat dan produktif. Sehingga Kota tidak hanya maju secara ekonomi, tapi juga maju secara ekologi. Pemerintah Daerah harus melakukan pengelolaan ruang terbuka hijau dengan memperhatikan etika dan estetika lingkungan sehingga ruang terbuka hijau ini dapat berfungsi secara maksimal terutama pada wilayah Kota Makassar. Pemerintah dalam hal ini berperan penting dalam pengelolaan ruang terbuka hijau.

Konsep good ataupun bad pada dasarnya adalah persoalan pijakan atau keberpihakan pada nilai-nilai tertentu. Kalau kita sepakat bahwa penilaain good atau bad perlu dilakukan dalam bingkai penghormatan terhadap kedaulatan ekosistem maka pemikiran tentang baik buruknya environmental govenance tidak harus dilihat dari kacamata antropesentrik, dalam kaitanya dengan keperluan untuk keluar dari pendekatan yang managerliastik tersebut di atas, perlu di cermati bahwa pemaknaan good governance dalam pengeloaan lingkungan hidup perlu dipastikan bahwa kita dapat terjebak dalam antroposentrisme, sungguhpun demikian, bukan berarti bahwa pemikiran tentang governance merupakan arti penting tentang pengkajian interaksi antar manusia.

\section{Environmental governance} merupakan interaksi dengan lingkungan hidup kita kelola dengan bingkai konseptual. Environmental governance adalah pada keperluan untuk memahami dan mengelola hubungan timbal balik antara sistem sosial dengan ekosistem, lebih dari itu pengeloaan sistem sosial perlu dikelola dengan mengedepankan nilai-nilai ekologis, dan sebaliknya ketahanan ekosistem bias dipelihara melalui pengelolaan sistem sosial yang terbimbing oleh kaidah-kaidah ekologis.

Pengelolaan ruang terbuka hijau ini diharapkan tidak hanya dapat meningkatkan kualitas dan daya dukung 
lingkungan hidup di perkotaan, tapi juga dapat menambah keindahan kota. Kondisi ini perlu mendapatkan perhatian dari semua pihak terutama Pemerintah Kota Makassar khususnya Dinas Pertamanan dan Kebersihan untuk itu sosialisasi perlu dilakukan, karena betapapun baiknya perencanaan, penataan dan pengembangan ruang terbuka hijau di Kota, di samping itu harus di dukung dengan keterlibatan warga masyarakat dan pihak swasta dalam pengelolaan ruang terbuka hijau tersebut agar terwujudnya pengelolaan lingkungan secara baik dan benar sehingga menambah kelestarian dan keindahan taman Kota.

Fakta inilah yang terjadi pada tata kelola ruang terbuka hijau pada salah satu Taman yang berada di Kota Makassar yaitu pengelolaan Taman Macan yang mana pengelolaan Taman ini terlihat telah terlaksana tata kelola lingkungan yang baik, dalam hal ini pemerintah yang berperan mengelola Taman Macan ini adalah Dinas Pertamanan dan Kebersihan telah melaksanakan fungsinya dengan baik dalam mengelola Taman ini. Taman Macan telah difungsikan masyarakat Kota Makassar sebagai tempat rekreasi dan di fungsikan sebagai Taman dan tempat berolahraga.

\section{B. KONSEP GOVERNANCE}

ENVIRONMENTAL

Pemikiran tentang good governance ini pertama kali di kembangkan oleh lembaga dana internasional seperti World Bank, United Nation Development Program (UNDP), dan International Moneter Finance (IMF) dalam rangka menjaga dan menjamin kelangsungan dana bantuan yang diberikan kepada negara sasaran bantuan, penyandang dana bantuan memandang bahwa setiap bantuan untuk negara-negara dunia terutama negara berkembang, sulit berhasil tanpa adanya good governance. Pada dasawarsa terakhir berkembang istilah governance dan good governance yang berkaitan dengan pelaksanaan pemerintahan dalam suatu negara. Secara umum, governance adalah proses pembuatan keputusan dan proses bagaimana keputusan diimplementasikan diberbagai tingkat pemerintahan.

Dalam good governance tidak lagi hanya pemerintah tetapi juga citizen, masyarakat terutama sektor usaha/swasta yang berperan dalam governance. Jadi ada penyelenggara pemerintah, penyelewengan swasta, dan organisasi masyarakat. Hal ini karena perubahan paradigma pembangunan dengan peninjauan ulang peran pemerintah dalam pembangunan, yang semula bertindak sebagai regulator dan pelaku pasar, menjadi bagaimana menciptakan iklim yang kondusif dan melakukan investigasi prasarana yang mendukung dunia usaha. Sudah barang tentu, ini bisa dilakukan apabila masyarakat dan sektor swasta sendiri sudah semakin mampu/berdaya. Justru sekarang adalah usaha pembangunan melalui koordinasi/sinergi (keselarasan kerja/interaksi) antara pemerintah masyarakat swasta. Mungkin dapat dilihat sebagai bentuk pemerintah memberdayakan masyarakat, terutama sektor usaha agar menjadi partner pemerintah (dalam Sentosa, 2001).

Menurut Wahab (Tangkilisan, 2005 : 34 ) menyebut good governance adalah suatu konsep dalam penyelengaraan manajemen pembangunan yang solid dan bertanggung jawab sejalan dengan demokrasi dan pasar yang efisien, penghindaran salah alokasi dan investasi yang langka dan pencegahan korupsi baik secara politik maupun administrative, menjalankan disiplin anggaran serta penciptaan legal and political framework 
bagi tumbuhanya aktivitas kewiraswastaan. Selanjutnya, menurut Ismanto (2005) good governance secara istilah merujuk pada kultur dan struktur pemerintahan yang menjalankan kekuasaan di dalam suatu negara, tidak hanya menyangkut lembaga eksekutif, namun seluruh Negara yang menyangkut penyelenggaraan kehidupan bernegara.

Menurut United Nation Development Pogram (UNDP) mengemukakan bahwa karakteristik atau prinsip-prinsip yang dikembangkan dala pemerintahan yang baik (good governance) adalah sebagai brikut : (1) Partisipasi : setiap orang atau setiap warga Negara baik laki-laki maupun perempuan harus memiliki hak suara yang sama dalam proses pengambilan keputusan, baik secara langsung maupun melalui lembaga perwakilan, sesuai dengan kepentingan dan aspirasinya masingmasing. Partisipasinya yang luas ini perlu dibangun dalam suatu tatanan kebebasan berserikat dan berpendapat, serta kebebasan untuk berpatsipasi secara konstruktif. (2) Aturan Hukum (Rule of Law) : Kerangka aturan hukum dan perundang-undangan haruslah berkeadilan ditegakkan dan dipatuhi secara utuh (impartially), terutama tentang aturan hukum tentang hak asasi manusia. (3) Transparansi : transparansi harus dibangun dalam kerangka kebebasan aliran informasi berbagai proses, kelembagaan harus dapat diakses secara bebas oleh mereka yang membutuhkanya, dan informasi harus dapat disediakan secara memadai dan mudah dimengerti, sehingga dapat digunakan sebagai alat monitoring dan evaluasi.

Untuk mengetahui gagasan dan praktek good governance, maka inti good governance adalah seni pemerintah yang berpihak pada rule of law dengan elemen transparansi, akuntabilitas, fairness, dan responsibility. Elemen-elemen tersebut menyadarkan kita bahwa good governance adalah seperangkat tindakan yang memberikan pagar yang lebih jelas dari proses pemerintahan dengan fungsi dan wewewangnya

Dari beberapa pemaparan mengenai good governance diatas terdapat beberapa unsur penting didalamnya dan saling berkesinambungan. Unsur-unsur dalam pemerintahan terdapat tiga macam unsur yaitu : (1) Negara/Pemerintah : konsepsi kepemerintahan pada dasarnya adalah kegiatan kenegaraan, tetapi lebih jauh dari itu melibatkan pula sektor swasta dan kelembagaan masyarakat madani. (2) Sektor swasta : pelaku sektor swasta mencangkup perusahaan swasta yang aktif dalam interaksi dalam sistem pasar, seperti : industri pengolahan perdangan, perbankan dan koperasi termasuk kegiatan sektor informal. (3) Masyarakat madani : kelompok masyarakat dalam konteks kenegaraaan pada dasarnya berada diantara atau ditengah-tengah antara pemerintah dan perseorangan, yang mencakup baik perseorangan maupun kelompok masyarakat yang berinteraksi secara sosial, politik dan ekonomi.

Berkaitan dengan good environmental governance dalam hal ini telah di bahas pada paragraf sebelumnya pemaparan tentang pengertian dari good governance, kemudian kita memaparkan arti dari environmental, dimana menurut Soemarwoto (2004 : 89), mendefinisikan lingkungan hidup (environmental) adalah jumlah semua benda dan kondisi yang ada dalam ruang yang kita tempati yang mempengaruhi kehidupan kita. Sedangkan menurut Michael (dalam Soemarwoto, 2004 : 56) mengemukakan lingkungan hidup (environmental) adalah the physical, chemical, and biotic, condition surrounding 
and organism (fisik, kimia, dan kondisi biotik sekitarnya dan organism).

\section{KONSEP PENGELOLAAN RUANG TERBUKA HIJAU (RTH)}

Ruang Terbuka Hijau adalah penataan ruang perkotaan yang berfungsi sebagai kawasan lindung, kawasan hijau pertamanan Kota, kawasan hijau hutan Kota, kawasan hijau rekreasi Kota, kawasan hijau kegiatan olahraga, kawasan hijau pemakaman, kawasan hijau pertanian, kawasan hijau jalur hijau dan kawasan hijau pekarangan (Kementerian Lingkungan Hidup, 2001). Sedangkan, berdasarkan Peraturan Menteri Dalam Negeri No. 1 Tahun 2007 tentang Penataan Ruang Terbuka Hijau Kawasan Perkotaan menyatakan bahwa Ruang Terbuka Hijau Kawasan Perkotaan adalah bagian dari ruang terbuka dalam suatu kawasan perkotaan yang diisi oleh tumbuhan dan tanaman guna mendukung manfaat ekologi, sosial, budaya, ekonomi dan estetika.

Ruang Terbuka hijau menurut Pasal 1 butir 3 Undang-Undang Nomor 26 Tahun 2007 Penataan Ruang adalah area memanjang/jalur atau mengelompok, yang penggunaanya lebih bersifat terbuka tempat tumbuh tanaman, baik yang tumbuh secara alamiah maupun yang sengaja ditanam, sehingga Ruang Terbuka Hijau (RTH) dalam kota merupakan pemanfaatan ruang terbuka yang bersifat pengisian hijau tanaman atau tumbuh-tumbuhan secara alaiah atau budidaya tanaman oleh manusia seperti jalur hijau, pertamanan, lahan pertanian, hutan kota (Wahyudi, 2009).

\section{FUNGSI DAN MANFAAT RUANG TERBUKA HIJAU (RTH)}

Dalam masalah perkotaan, Ruang Terbuka Hijau (RTH)merupakan bagian atau salah satu sub-sistem dari sistem Kota secara keseluruhan. Ruang Terbuka Hijau (RTH) sengaja dibangun secara merata diseluruh Wilayah Kota untuk memenuhi berbagai fungsi dasar yang secara umum dibedakan menjadi :

(1) Fungsi bio-ekologis (fisik), yang member jaminan pengadaan Ruang Terbuka Hijau (RTH) menjadi bagian dari sistem sirkulasi udara (paru-paru Kota), pengatur iklim mikro agar sistem sirkulasi udara dan air secara alami dapat berlangsung lancer, sebagai peneduh, produsen oksigan, penyerap air hujan, penyedia habitat satwa, penyerap (pengolah) polutan medianudara, air dan tanah, serta penahan angin. (2) Fungsi sosial, ekonomi (produktif) dan budaya yang mampu menggambarkan ekpresi budaya local, Ruang Terbuka Hijau (RTH) merupakan media komunikasi warga Kota, tempat rekreasi, tempat pendidikan, dan penelitian. (3)Ekosistem perkotaan : produsen oksigen, tanaman berbunga, berbuah dan berdaun indah, serta bisa menjadi bagian dari usaha pertanian, kehutanan dan lain-lain. (4) Fungsi estetis, meningkatkan kenyamanan, memperindah lingkungan Kota baik (dari skala mikro: halaman rumah, lingkungan pemukiman, maupun makro : lansekap kota secara keseluruhan).

\section{E. KONSEP KOLABORASI AKTOR GOVERNANCE}

Kerja sama antara pemerintah daerah dan swasta merupakan terobosan yang biasa dilakukan dalam menunjang keberhasilan pengelolaan lingkungan hidup. Selain itu, pelibatan swasta dan masyarakat dalam pengelolaan lingkungan 
hidup sejalan dengan prinsip tata kepemerintahan yang baik atau good governance yang dewasa ini menjadi trend atau kecendrungan global sebagai model dalam penyelenggaraan pemerintah secara umum. Tata kepemerintahan yang baik menekankan bahwa penyelenggaraan kepemerintahan diperlukan keseimbangan interaksi dan keterlibatan antara pemerintah, dunia usaha (swasta), dan masyarakat (civil society).

Kolaborasi merupakan bentuk kerja sama, interaksi, kompromi beberapa elemen yang terkait baik individu, lembaga dan atau pihak-pihak yang terlibat secara langsung dan tidak langsung yang menerima akibat dan manfaat. Nilai-nilai yang mendasari sebuah kolaborasi adalah tujuan yang sama, kesamaan persepsi, kemauan untuk berproses, saling memebrikan manfaat, kejujuran, kasih saying serta berbasis masyarakat. (CIFOR/PILI 2005). Berdasarlan kamus Heritage Amerika (2000), kolaborasi adalah bekerja bersama khusunya dalam penggambungkan pemikiran.

\section{F. METODE PENELITIAN}

Jenis penelitian yang digunakan adalah kualitatif yaitu metode yang digunakan adalah penekanan pada observasi wawancara untuk orang, sebagai lawannya adalah gambaran kondisi objektif secara ilmiah, dimana peneliti adalah sebagai instrument kunci, teknik pengumpulan data dilakukan secara triangulasi (gabungan) analisis data bersifat induktif dan hasil penelitian kualitatif lebih menekankan makna daripada generalisasi.

Tipe penelitian ini adalah penelitian deskriptif kualitatif yakni suatu bentuk penelitian yang bertujuan memberikan gambaran umum berbagai macam data yang dikumpul dari lapangan secara objektif, sedangkan dasar penelitiannya adalah survey yakni tujuan dari penelitian deskriptif ini adalah menggambarkan mengenai situasi-situasi atau kejadiankejadian secara sistematis, factual dan akurat mengenai fakta-fakta dari pengelolaan Taman Macan yang berada di Kota Makassar.

\section{G. HASIL DAN PEMBAHASAN}

Dalam pengenalan tata kelola (governance), penulis menjabarkan cara tata kelola lingkungan yang baik (good environmental governance) dimana pada pengelolaan lingkungan yang baik ini terdapat beberapa kerja sama antara pihak pemerintah, non pemerintah (swasta) dan masyarakat . Pemerintah Kota Makassar dalam hal ini Dinas pertamanan dan kebersihan sebagi pengelola Taman Macan. Berikut beberapa prinsip-prinsip yang di gunakan dalam good environmental governance yaitu :

\section{Partisipasi}

Partisipasi adalah proses ketika warga, sebagai individu maupun kelompok sosial dan organisasi, mengambil peran serta ikut mempengaruhi proses perencanaan, pelaksanaan dan pemantauan kebijakan-kebijakan yang langsung mempengaruhi kehidupan mereka. Keterlibatan aktif atau partisipasi masyarakat dapat berarti keterlibatan dalam proses penentuan arah, strategi dan kebijaksanaan pembangunan yang dilakukan pemerintah.

Partisipasi merupakan pengambilan bagian atau keterlibatan anggota masyarakat dengan cara memberikan dukungan (tenaga, pikiran maupun materi) dan tanggung jawabnya terhadap setiap 
keputusan yang telah diambil demi tercapainya tujuan yang telah ditentukan bersama. Ada beberapa pihak yang berpartisipasi dalam pengelolaan taman macan yang berada di Kota Makassar, diantaranya pemerintah Kota Makassar dalam hal ini Dinas Pertamanan dan Kebersihan sebagai pengelola taman dimana Dinas pertamanan sebagai pelaksana pembangunan, penataan dan pengembangan fungsi-fungsi taman macan. Dalam pengelolaan taman macan seksi pemeliharaan taman dalam hal ini melakukan hal-hal sebagai berikut : (a) Melaksanakan penyusunan rencana dan program kerja seksi pembangunan taman. (b) Penyiapan dan pelaksanaan program kegiatan pembangunan dan penataan Taman-Taman Kota. (c) Melaksanakan pemeliharaan Taman Kota, pengawasan dan pengendalian tata keindahan (dekorasi) kota.

Bentuk partisipasi yang dilakukan pemerintah terhadap pengelolaan Taman Macan. Sebagai berikut hasil wawancara dengan kepala seksi pemeliharaan Taman yang terkait tentang bagaimana cara dalam pengeloaan (governance) taman macan sehingga terwujudnya good environmental governance di Kota Makassar menyatakan :

"Menurut saya pada dinas ini terbagi beberapa bidang diantaranya yaitu seksi pembangunan taman dimana pada bidang ini melakukan pemeliharaan taman, terbagi beberapa kelompok ada yang bekerja sama melakukan pemeliharaan taman, ada yang melakukan pengawasan terhadap pengelola yang melakukan pemeliharaan taman"(wawancara, IL)

Berdasarkan hasil wawancara dengan kepala seksi pembangunan taman dapat disimpulkan bahwa partisipasi pemerintah terhadap pengelolaan taman macan sehingga terwujudnya pengelolaan taman yang baik adalah pemerintah sebagai pengelola, sekaligus melakukan pengawasan agar terwujudnya tata kelola taman yang baik.

Sehubungan dengan partisipasi pada pihak swasta dalam hal Bank BRI maka, pihak BRI mengadakan suatu kegiatan yang bernama BRI Peduli. Dalam kegiatan ini, pihak BRI hanya memberikan sumbangsi, berupa tempat sampah untuk membantu menjaga kebersihan pada Taman Macan yang berada di Kota Makassar. Mengenai partisipasi pihak swasta dalam pengelolaan Taman Macan yang berada di Kota Makassar, berikut hasil wawancara dengan salah satu informan yang menyatakan :

"Sekitar 5 tahun yang lalu pihak bank kami melaksanakan kegiatan BRI Peduli yang pelaksanaanya memberikan tempat sampah pada taman-taman yang telah di tentukan, salah satunya yaitu taman macan. Kami hanya sekedar memberikan sumbangsi berupa tempat sampah namun tidak memiliki keterkaitan ataupun kerja sama dalam pengelolaan taman macan dengan Dinas Pertamanan dan Kebersihan Kota Makassar" (wawancara HD).

Berdasarkan hasil wawancara pada salah satu staf sekertaris Bank BRI maka dapat disimpulkan bahwa partisipasi pihak swasta dalam pengelolaan Taman Macan adalah pihak swasta hanya memberikan bantuan. Bank BRI tidak ada program yang berkelanjutan antara pihak pemerintah Kota dan pihak swasta.

Masyarakat sebagai penguna taman yang sering menggunakan fasilitas yang ada sebagai sarana olahraga maupun sebagai tempat rekreasi. Bentuk lain dari partisipasi masyarakat dalam pengelolaan 
Taman Macan dengan melakukan pengawasan terhadap kinerja pada pengelolaan taman. Masyarakat dapat memberikan kritik yang membangun terhadap pengelola taman sehingga pengelolaan pada Taman Macan dapat lebih baik.

Hasil wawancara dengan salah satu informan yang terkait partisipasi masyarakat pada pengelolaan Taman Macan satu menyatakan bahwa:

"kami hampir setiap hari melakukan aktivitas disekitar Taman ini seperti berolahraga, beristirahat dengan teman kantor saya pada saat jam istirahat kerja, kami selaku pengguna Taman memberikan saran pada pengelola taman atau pengawai pengawas taman terhadap sarana yang masih kurang dan yang perlu dibenahi pada Taman Macan ini."(wawancara, $Y N$ ).

Berdasarkan hasil wawancara kepada masyarakat terkait partisipasi masyarakat dalam pengelolaan Taman Macan dapat disimpulkan bahwa masyarakat juga memiliki fungsi memperbaiki taman macan kearah yang lebih baik. Masyarakat pengguna taman dapat melakukan koordinasi dengan pemerintah kota Makassar dalam pengawasan terhadap kinerja pengelola taman, dalam hal ini Dinas Pertamanan dan Kebersihan Kota Makassar, dengan cara memberikan saran atau kritik yang membangun terhadap pengelolaan Taman Macan.

Berdasarkan hasil observasi peneliti terhadap partisipasi pemerintah, swasta dan masyarakat dalam pengelolaan Taman Macan, peneliti dapat menyimpulkan bahwa peran pemerintah Kota lebih pada menyiapkan fasilitas pada Taman Macan. Pengawasan yang dilakukan pemerintah
Kota secara terjenjang sesuai tingkatan pemerintah dalam pemeliharaan taman. Selain itu, pihak swasta masih perlu memperhatikan pemeliharaan bank sampah yang diletakkan di Taman Macan.

\section{Rule Of Law (Aturan Hukum)}

Aturan Hukum (rule of law) merupakan Kerangka aturan hukum dan perundang-undangan haruslah berkeadilan ditegakkan dan dipatuhi secara utuh (impartially), terutama tentang aturan hukum tentang hak asasi manusia. Rule of Law sebagai suatu institusi sosial yang memiliki struktur sosial sendiri dan memperakar budaya sendiri . rule of law tumbuh dan berkembang ratusan tahun seiring dengan pertumbuhan masyarakat Eropa, sehingga memperakar sosial dan budaya eropa, bukan institusi netral. Pengertian rule of law berdasarkan subtansi atau isinya sangat berkaitan dengan peraturan perundang-undangan yang berlaku dalam suatu negara. Konsekuensinya setiap Negara akan mengatakan mendasarkan pada rule of law dalam kehidupan Negaranya, meskipun Negara tersebut adalah Negara otoriter. Atas dasar alasan ini maka diakui bahwa sulit menentukan pengertian rule of law secara universal, karena setiap masyarakat melahirkan pengertian yang berbeda-beda. Dalam hubungan ini maka rule of law dalam hal munculnya bersifat endogen, artinya muncul dan berkembang dari suatu masyarakat tertentu.

Berkaitan dengan penjelasan tentang rule of law berikut hasil wawancara dengan salah informan yaitu kepala bidang pertamanan yang menyatakan :

"Adapun peraturan pemerintah
tentang Dinas Pertamanan Dan
Kebersihan yang tertera pada
peraturan daerah Kota Makassar


nomor 3 tahun 2009 pada pasal 26 yang menyatakan bahwa dinas pertamanan dan Kebersihan mempunyai tugas pokok merumuskan, membina dan mengendalikan kebijakan di bidang pertamanan, penghijauan, tata keindahan (dekorasi) kota ".( wawancara, IL).

Dari hasil wawancara dengan salah satu informan kepala bidang pertamanan, maka dapat dinyatakan bahwa pemerintah harus mempunyai aturan hukum atau landasan dalam pengelolaan lingkungan dan pengelolaan. Pemerintah tidak dapat melakukan pengelolaan taman melainkan harus mempunyai landasan hukum/Peraturan pemerintah yang di tetapkan oleh pemerintah setempat.

Dalam Perturan daerah Kota Makassar Nomor 3 Tahun 2009 pada pasal 26 pasal 1 telah dijabarkan bahwa Dinas Pertamanan dan Kebersihan mempunyai tugas pokok merumuskan, membina, dan mengendalikan kebijakan di bidang pertamanan, penghijauan, tata keindahan (dekorasi) kota, peyelenggaraan kebersihan/persampahan, pengelolaan pemakaman dan Tempat Pengelolaan Akhir Sampah (TPA). Sesuai dengan penjelasan pada PERDA Kota Makassar tentang tugas pokok Dinas Pertamanan dan Kebersihan diantaranya telah dijelaskan bahwa pemerintah mempunyai tugas pokok dalam pengelolaan taman yaitu sebagai Pembina dan pengelola pada bagian pertamanan.

Berdasarkan dengan penjelasan tentang rule of law (aturan hukum) berikut hasil wawancara dengan salah satu informan staf SDM dan refresentatif atau HRD (Human Refresentatif Development) mengenai pengelolaan Taman Macan bahwa: "kami melihat taman yang aktif di daerah sekitar kantor adalah taman macan yang memiliki padat pengunjung sehingga kami melaksanakan program BRI peduli berupa memberikan beberapa bank sampah (temapt sampah) di letakkan dalam taman macan yang merupakan salah satu program kerja di kantor Kami". (wawancara, AD)

Dari hasil wawancara dengan salah satu informan pegawai Bank BRI cabang ahmad yani, maka dapat disimpulkan bahwa kegiatan yang dilakukan oleh pihak swasta yakni memberikan tempat sampah merupakan salah satu wujud kebijakan yang di terapkan oleh pemerintah Kota Makassar menjaga kebersihan Kota Makassar.

Berdasarkan dengan penjelasan tentang rule of law (aturan hukum), berikut hasil wawancara dengan salah satu informan yang berkunjung ke Taman Macan yang menyatakan bahwa :

"Kondisi taman macan saat ini membuat pengujung tidak nyaman untuk bersantai, karna kondisi Taman Macan telah banyak mengalami perubahan. Dalam menjaga kenyamanan pengunjung yang tiba di Taman Macan, pengelola taman seharusnya menanami rumput di bagian tanah yang berdebu dan tumbuhan yang tumbuh diseragamkan jenisnya agar terlihat rindang dan indah." (wawancara, ID).

Dari hasil wawancara dengan salah satu informan yang berkunjung ke Taman macan, maka dapat dinyatakan bahwa masyarakat memiliki peran menjaga kelestarian lingkungan hidup seperti memberikan saran sehingga pengelola 
Taman dapat meningkatkan kualitas pemeliharaan taman. Dengan pernyataan salah satu informan yang berkunjung ke Taman Macan, maka terjabarkan bahwa fungsi masyarakat dalam perlindungan dan pengelolaan lingkungan hidup dalam Undang-Undang Nomor 32 Tahun 2009 pada pasal 70 telah terlaksanakan dengan baik.

Berdasarkan hasil observasi peneliti terhadap rule of law pada pengelolaan Taman Macan yang dilakukan oleh pemerintah, swasta dan masyarakat telah dijabarkan bahwa pada fungsi masingmasing unsur yang terlibat dalam pengelolaan taman macan. Namun, peran pemerintah dalam pengelolaan Taman Macan masih perlu ditingkatkan sehingga taman macan ini dapat berfungsi dengan baik.

\section{Transparansi}

Transparansi adalah adanya kebijakan terbuka bagi pengawasan. Sedangkan yang dimaksud dengan informasi adalah informasi mengenai setiap aspek kebijakan pemerintah yang dapat dijangkau public. Keterbukaan informasi diharapkan atau menghasilkan persaingan politik yang sehat, tolerban, dan kebijakan dibuat berdasarkan referensi public. Sehubungan dengan pengertian sebelumnya transparansi berarti keterbukaan (opennsess) pemerintah dalam memberikan informasi yang terkait dengan aktivitasi pengelolaan sumber daya public kepada pihak-pihak yang membutuhkan informasi.

Berkaitan dengan penjelasan mengenai transparansi berikut hasil wawancara dengan salah satu staf bidang pertamanan yang menyatakan :

"kami di dinas pertamanan dan kebersihan khususnya di bidang pertamanan dalam melakukan tugas saling terbuka antara pihak pengelola taman macan dengan pegawai tentang pengelolaan anggaran yang digunakan untuk pemeliharaan taman. kami sering melakukan pengawasan pada kinerja pengelola taman dan setiap anggaran yang di berikan kepada pengelola untuk memperbaiki fasilitas yang kurang lengkap yang berada di taman macan".(wawancara, $A G$ ).

Berdasarkan hasil wawancara dari salah satu informan pada dinas kebersihan dan pertamanan tentang transparansi maka dapat disimpulkan bahwa adanya keterbukaan dalam pengelolaan anggaran merupakan wujud transparansi yang dilakukan oleh pemerintah dalam kerja sama antara pihak pengelola taman macan dengan staf di dinas pertamanan dan kebersihan pada pengelolaan taman macan.

Berikut hasil wawancara dengan salah satu informan yaitu sekertaris Bank BRI cabang Ahmad Yani yang menyatakan bahwa:

"sumbangsi berupa beberapa tempat sampah yang kami berikan kepada pengelola taman macan, diserahkan secara langsung tanpa melalui perantara. Kami melaksanakan kegiatan ini sehubungan dengan program kerja dari kantor kami dan merupakan slah satu wujud kepedulian terhadap lingkungan". (wawancara, HD)

Berdasarkan hasil wawancara dengan salah satu informan pada pihak swasta, maka penulis dapat menyimpulkan bahwa keterbukaan dalam penyediaan tempat sampah yang diberikan oleh pihak 
swasta kepada pengeola taman dilakukan secara langsung tanpa melaui perantara. Dengan adanya sumbangsi pihak swasta melalui penyediaan tempat sampah, maka terjabarkan bahwa pihak swasta mempunyai mempunyai kepedulian terhadap lingkungan.

Sehubungan dengan penjelasan yang terkait dengan transparansi, berikut hasil wawancara dengan salah satu informan masyarakat yang berkunjung di Taman Macan yang menyatakan bahwa :

"Kami melihat Berbagai tingkatan, remaja, para pegawai, maupun lanjut usia tumpah ruah memenuhi taman sambil jalan kaki, ada juga ibu rumah tangga yang membawa serta anaknya dengan memakai sepeda mini, Taman Macan adalah salah satu space publik yang menjadi dambaan warga kota Makassar untuk berolah raga. (wawancara, YN)

Berkaitan dengan penjelasan mengenai transparansi berikut hasil wawancara dengan salah satu masyarakat yang berkunjung ke Taman Macan, maka dapat disimpulkan bahwa masyarakat telah merasa puas dengan fasilitas yang berada di Taman Macan. Taman Macan telah menjadi saran untuk berolahraga bagi masyarakat sekitar Taman Macan, merupakan salah satu bukti keberhasilah transparansi pemerintah dalam melakukan pengelolaan taman macan sehingga pengunjung merasa puas dan nyaman melakukan aktivitas disekitar taman macan.

Berdasarkan observasi peneliti, transparansi yang dilakukan pemerintah, swasta dan masyarakat dalam pengelolaan Taman Macan maka dapat disimpulkan bahwa telah diterapkan dengan baik.

\section{Bentuk Kolaborasi Pemerintah, Swasta Dan Masyarakat}

Pemerintah sebagai lembaga tertinggi dalam suatu Negara berwenang untuk mengatur ataupun mengendalikan apa saja yang berkaitan dengan pengelolaan lingkungan hidup di Indonesia, dan untuk mengimplementasikannya maka pemerintah melakukan pengawasan , pemerintah merupakan bagian dari masyarakat dan masyarakat memiliki hak, kewajiban dan peran yang sama dalam pengelolaan lingkungan, tanpa terkecuali masyarakat desa, pelosok maupun kota, karena ruang lingkup lingkungan bukan hanya ditempat-tempat tertentu saja namun seluruh wilayah Negara Kesatuan Republik Indonesia.

Keberadaan masyarakat akan efektif jika peranya dalam mengontrol pengelolaan lingkungan yang ada. Pemerintah merupakan salah satu unsur yang terlibat dalam pengelolaan taman macan yang berada di Kota Makassar berikut hasil wawancara dengan kepala seksi pemeliharaan taman yang menyatakan bahwa:

"kami dari pemerintah melakukan pengawasan terhadap pemeliharan taman macan, yaitu kami melakukan peninjauan terhadap kinerja pengelola taman macan dan pengawai dari pemerintahan mengawasi secara langsung kinerja pengelola taman".(Wawancara IL).

Berdasarkan hasil wawancara dengan pegawai Dinas Pertamanan dan Kebersihan yang menyatakan bahwa kolaborasi antara pihak pemerintah bersama masyarakat terlihat pada peran pemerintah dalam meninjau atau melakukan pengawasan terkait pemeliharaan taman yang dilakukan oleh 
pengelola Taman. Sehubungan dengan pengawasan yang dilakukan oleh pemerintah terhadap pemeliharaan Taman, pemerintah juga merupakan bagian dari pengelola taman yang bertugas memelihara Taman, berdasarkan hasil wawancara dengan salah satu pengelola taman yang merupakan pegawai pemerintah sebagai penanggung jawab sekaligus pengelola taman macan yang menyatakan bahwa :

"saya disini sebagai pengelola taman juga bagian dari pegawai dinas pertamanan dan kebersihan, saya juga PNS(Pegawai Negeri Sipil) tetapi saya ditugaskan langsung untuk mengelola taman macan ini karna saya berada di staf pemeliharaan taman, disini kami bekerja setiap hari merawat taman macan ini, jam kerja kami sesuai dengan jam kerja yang berada pada kantor dinas. Masyarakat yang berkunjung disini jika mereka merasa tidak nyaman dengan kebersihan taman terkadang mereka mengeluh kepada salah satu dari kami sebagai pengelola taman. (Wawancara, SR).

Berdasarkan dari hasil wawancara dengan penanggung jawab pengelola Taman Macan yang juga merupakan salah satu pegawai Dinas Pertamanan Dan Kebersihan dapat disimpulkan bahwa kolaborasi antara pemerintah dan masyarakat terlihat pada keluhan masyarakat jika terjadi kesalahan pada pengelolaan taman macan sehingga pengelola dapat melakukan pemeliharaan lebih baik dan membenahi kekurangan yang ada pada pengelolaan Taman Macan. Terkait dengan wawancara yang dilakukan kepada salah satu pengelola Taman Macan yang mana terdapat beberapa kerja sama antara Pegawai Dinas Pertamanan Dan
Kebersihan dengan pengelola Taman yaitu pengelola Taman juga merupakan pegawai dinas pertamanan dan kebersihan yang ditugaskan bekerja pada pengelolaan taman.

Swasta adalah untuk meningkatkan pelayanan publik. Hal itu juga dilatarbelakangi oleh adanya keterbatasan pendanaan maupun rendahnya kualitas pelayanan (inefisien dan inefektif) dari pemerintah sebagai penyedia pelayanan publik. Pada hakekatnya, pelibatan sektor swasta dalam pengembangan saranaprasarana akan memberikan keuntungan baik bagi pemerintah maupun swasta. Bagi sektor swasta keuntungan yang didapat dengan mekanisme ini adalah profit. Adapun keuntungan bagi pemerintah, adalah mempermudah proses, waktu penyediaan serta meringankan beban pendanaan untuk memenuhi kebutuhan sarana prasarana perkotaan. Keuntungan lain yang diperoleh pemerintah adalah terciptanya transfer teknologi dan efesiensi managerial dari pihak swasta yang dikombinasikan dengan rasa tanggung jawab serta kepedulian terhadap lingkungan.

Dalam sektor swasta pengelolaan sumberdaya masyarakat. Meskipun demikian, inisiatif keikutsertaan mitra kerja dan stakeholders juga dapat berasal dari sektor swasta menegaskan bahwa keterlibatan stakeholders sangat penting pada saat penyusunan rona lingkungan untuk sebuah perusahaan. Mereka menegaskan bahwa sistem untuk ukuran penampilan lingkungan (SIPIL) perlu dimiliki karena adanya beberapa kenyataan, selain mempunyai dampak ekonomi, dalam kegiatan juga mempunyai dampak lingkungan dan sosial. menjadi bertanggungjawab untuk lingkungan, seperti ditunjukkan dengan meningkatnya jumlah peraturan, insentif dan denda; dan 
Melibatkan pengelolaan lingkungan kedalam perusahaan merupakan "upaya yang baik" karena dapat mengurangi biaya secara langsung atau meningkatkan reputasi secara tidak langsung.

Berikut hasil wawancara dengan staf Sekertaris BRI cabang ahmad yani yang menyatakan bahwa:

"kami hanya melakukan kegiatan sosial berupa BRI peduli yang pada kegiatan tersebut pihak Bank memberikan sumbangan berupa beberapa Bank sampah (tempat sampah) yang diberikan kepada pengelola taman macan dan ditempatkan pad ataman macan".(wawancara, HD).

Berdasarkan hasil wawancara dengan pihak swasta yaitu pihak Bank BRI Ahmad yani dapat disimpulkan bahwa kerja sama (Kolaborasi) yang dilakukan pihak swasta dalam pengelolaan Taman dapat dilihat pada kegiatan yang dilaksanakan pihak Bank BRI berupa BRI peduli yang menyumbangkan beberapa Bank sampah kepada pengelola taman macan yang diletakkan dibagian taman untuk memberikan kesadaran terhadap masyarakat yang berkunjung ke taman macan akan kesadaran menjaga kebersihan. Sebagai wujud kepedulian pihak swasta yang telah melaksanakan salah satu kegiatan yaitu BRI peduli, pihak swasta telah terlibat dalam pengelolaan Taman Macan yang sesuai dengan salah satu unsur yang berperan dalam governance, walaupun hanya memberikan sumbangsi berupa Bank sampah (tempat sampah) namun pihak swasta telah berperan sesuai fungsinya sebagai salah satu unsur atau stakeholder dalam governance.

Masyarakat merupakan sistem sosial yang subur berdasarkan prinsip-prinsip moral yang menjamin kesimbangan antara kebebasan individu dengan kestabilan masyarakat, inisiatif dari individu dan masyarakat akan berupa pemikiran, seni, pelaksanaan pemerintah yang berdasarkan undang-undang dan bukan nafsu atau keinginan individu. Sektor publik adalah bidang kajian yang berkaitan dengan publik/masyarakat. Kajian sektor publik bisa diidentifikasi terdapat tiga elemen didalamnya yaitu mendefinisikan sektor publik sebagai suatu identitas yang aktivitasnya pelayanan publik dalam rangka memenuhi kebutuhan dan hak publik memiliki wilayah yang lebih luas dan kompleks dibandingkan dengan sektor swasta. Keluasan wilayah publik ini tidak hanya disebabkan luasnya jenis dan bentuk organisasi yang berada didalamnya, akan tetapi juga karena kompleksnya lingkungan yang mempengaruhi lembaga-lembaga publik tersebut.

Secara kelembagaan, publik antara lain meliputi badan-badan pemerintahan, Lembaga Swadaya Masyarakat (LSM), organisasi nirlaba lainnya. Jika dilihat dari variabel lingkungan, sektor publik dipengaruhi oleh banyak faktor akan tetapi faktor politik, sosial, budaya, dan historis juga memiliki pengaruh yang signifikan. berdasarkan hasil wawancara dengan salah satu masyarakat yang berkunjung ke Taman Macan yang menyatakan bahwa:

"hampir setiap hari saya berkunjung ke taman ini berolahraga, berekreasi bersama anak saya. Saya melihat pekerja disini rajin-rajin tapi jika saya berkunjung waktu sore kadang tidak ada pekerja yang terlihajat, pernah saya melihat petugas berpakaian dinas berada di sini dan mengajak saya berbicara bertanya kepada saya bagaimana kenyamanan saya menggunakan taman macan ini dan saya juga menjawab jika masalah kenyamanan saya merasa 
nyaman tetapi terkadang masih belum puas dengan kebersihan taman ini, sering terlihat dedaunan berserakan dan tidak ada petugas yang membersihkan, fasilitas taman masih kurang seperti masih perlu di perbaiki tempat duduknya". (wawancar, ID).

Berdasarkan hasil wawancara dengan salah satu pengunjung Taman Macan dapat disimpulkan bahwa kerja sama (kolaborasi) antara masyarakat dengan pemerintah dapat terlihat pada keluhan masyarakat tentang pemeliharaan taman yang dilakukan oleh pihak pengelola yang berasal dari pemerintah itu sendiri. sehubungan dengan itu, pihak pemerintah dapat melakukan pembenahan dengan kinerja pengelola dari keluhan masyarakat sehingga pengelolaan Taman Macan yang selama ini telah terlihat baik dapat meningkat ke arah yang lebih baik.

Dari beberapa elemen yang terlibat dalam pengelolaan taman macan seperti yang dijelaskan pada paragraph sebelumnya dapat disimpulkan bahwa melalui tahap kolaborasi yang paling banyak berperan pada pengelolaan Taman Macan yang berada di Kota Makassar adalh pemerintah, pemerintah mempunyai Tugas utama dalam pengelolaan Taman Macan yang bekera sama dengan pihak swasta dan masyarakat. Dengen melakukan kerja sama (kolaborasi) pemerintah dapat melakukan pengelolaan dengan baik.

Sehubungan dari pada itu, pemerintah berperan penting dalam pengelolaan taman macan yaitu dinas pertamanan dan kebersihan melakukan kebijakan dengan menjalankan tugas dan fungsinya sebagai pemerintah yaitu mengayomi masyarakat dengan mendengarkan keluhan masyarakat dan yang menjadi kebutuhan masyarakat dapat dilihat pada pengawasan yang dilakukan bukan hanya pada pemeliharaan Taman yang dilakukan oleh pengelola namun pemerintah juga melakukan pendekatan terhadap masyarakat untuk mengetahui kekurangan fasilitas yang dapat dibenahi agar pengunjung Taman Macan merasa nyaman berada di Taman tersebut.

\section{H. PENUTUP}

Berdasarkan hasil penelitian yang dilakukan maka penulis menyimpulkan sebagai berikut: (1) Tata kelola lingkungan yang dilakukan oleh pemerintah dalam pengelolaan Taman Macan menggunakan prinsip Good Environmental yaitu : (a) partisipasi : bentuk partisipasi pemerintah terhadap pengelolaan Taman Macan ialah pemerintah sebagai pengelola taman (pemelihara) sekaligus pemerintah juga (pegawai Dinas Pertamanan Dan Kebersihan) juga melakukan pengawasan terhadap kinerja pengelola Taman (pemelihara). (b) rule of law (aturan hukum) : Adapun peraturan pemerintah tentang Dinas Pertamanan Dan Kebersihan yang tertera pada peraturan daerah Kota Makassar nomor 3 tahun 2009 pada pasal 26 yang menyatakan bahwa dinas pertamanan dan Kebersihan mempunyai tugas pokok merumuskan, membina dan mengendalikan kebijakan di bidang pertamanan, penghijauan, tata keindahan (dekorasi) kota. (c) Transparansi : Transparansi, adanya saling keterbukaan baik dalam hal pengawasan pengelolaan Taman maupun dalam kerja sama antara pegawai dinas dan pengelola Taman. (2) Bentuk Kolaborasi Pemerintah, Swasta Dan Masyarakat Dalam Pengelolaan Taman Macan adalah pemerintah sebagai pengelola Taman sekaligus pengawas terhadap pemeliharaan taman macan bekerja sama dengan pihak swasta dan 
masyarakat. Sehubungan dengan itu, swasta memeberikan sumbangsi melalui sebuah kegiatan sosial berupa BRI peduli yang menyumbangkan beberapa Bank sampah ke taman macan. Sedangkan, masyarakat bekerja sama dengan pemerintah dalam hal pengelolaan taman macan yang mana masyarakat sebagai pengunjung sekaligus pengamat terhadap kekurangan yang perlu di benahi pada Taman Macan yang berada di Kota Makassar.

\section{DAFTAR PUSTAKA}

Hakim, Rustam. 2010. Ruang Terbuka dan Ruang Terbuka Hijau. Jakarta : Universitas Trisakti.

Soemarwoto, Otto, 2004. Ekologi, Lingkungan Hidup dan Pembangunan, Jakarta: Djambatan.

Tangkilisan, Hessel Nogi S, 2005, Manajemen Publik, Jakarta : Grasindo.

Wahyudi, 2009. Ketersediaan Alokasi Ruang Terbuka Hijau Kota Pada Ordo Kota I Kabupaten. Tesis (tidak dipublikasi) Program Pascasarjana. Semarang : Universitas Diponegoro.

Dokumen :

Undang- Undang Nomor 32 Tahun 2009 Tentang Perlindungan Dan Pengelolaan Lingkungan Hidup.

Peraturan Daerah Kota Makassar Nomor 3 Tahun 2009 Tentang Pembentukan Dan Susunan Organisasi Perangkat Daerah Kota Makassar. 